\title{
Incorporating IFRS Into The U.S. Financial Reporting System
}

\author{
Wing W. Poon, Ph.D., Montclair State University, USA
}

\begin{abstract}
The SEC issued the "Commission Statement in Support of Convergence and Global Accounting Standards" in February 2010 to reaffirm its position that IFRS was best positioned to serve as the single set of high-quality globally accepted accounting standards and indicated that its staff would continue its evaluation of IFRS and a determination was expected to be made in 2011 as to whether, when, and how to incorporate IFRS into the financial reporting system for U.S. issuers. However, 2011 has come and gone and the SEC still has not yet made a decision. The SEC has indicated that it will not incorporate IFRS into the financial reporting system for U.S. issuers unless such a change is in the best interest of U.S. investors and capital markets. Whatever decision eventually made by the SEC, hopefully, is indeed the most beneficial one for U.S. investors and capital markets. This paper provides an overview of the possible incorporation of IFRS into the U.S. financial reporting system.
\end{abstract}

Keywords: IFRS and the U.S. Financial Reporting System; International Financial Reporting Standards; IFRS and SEC; IFRS and GAAP

\section{INTRODUCTION}

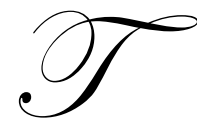

he Securities and Exchange Commission (SEC) issued the "Commission Statement in Support of Convergence and Global Accounting Standards" (2010 Statement) in February 2010 to reaffirm its position that International Financial Reporting Standards (IFRS) ${ }^{1}$ was best positioned to serve as the single set of high-quality globally accepted accounting standards and indicated that its staff would continue its evaluation of IFRS and a determination was expected to be made in 2011 as to whether, when, and how to incorporate IFRS into the financial reporting system for U.S. issuers. ${ }^{2}$ The "Work Plan for the Consideration of Incorporating International Financial Reporting Standards into the Financial Reporting System for U.S. Issuers" (Work Plan) included as an appendix to the 2010 Statement, detailed six specific areas of consideration for the SEC staff to address before a potential move to a system incorporating IFRS. However, 2011 has come and gone and the SEC still has not yet made a decision. Based on the statements given by the SEC Chief Accountant James Kroeker at the American Institute of Certified Public Accountants (AICPA) conference in December 2011, it appears that the SEC will not make a decision until the second half of 2012, at the earliest. This paper provides an overview of the possible incorporation of IFRS into the U.S. financial reporting system.

\section{IFRS}

The international standard-setting process began in 1973 with the formation of the International Accounting Standards Committee (IASC) by representatives from many of the large developed countries. The goal of the IASC was to create accounting standards that could be used by developing and smaller countries unable to establish their own standards. With the continuing globalization of business and finance, investors, regulators, large companies,

\footnotetext{
${ }^{1}$ The term "IFRS" refers to IFRS as issued by the International Accounting Standards Board and those International Accounting Standards (IAS) not yet superseded by IFRS, unless otherwise noted.

${ }^{2}$ U.S. issuers are those U.S. companies that have publicly listed securities and have to file their financial statements with the SEC. Since 2008, foreign companies that have publicly listed securities in the U.S. have been allowed to use IFRS, without reconciliation to U.S. GAAP, in their SEC filings.
} 
and accounting firms began to realize the importance of a single set of globally accepted accounting standards. In 1998, a core set of IAS was completed by the IASC and in 2000, the International Organization of Securities Commission, of which the SEC is a member, recommended that its members allow companies to use these standards in cross-border listings. In 2001, the IASC Foundation was created and the International Accounting Standards Board was established as the successor organization to the IASC and charged for the development of IFRS. The IASC Foundation changed its name to IFRS Foundation in 2010, as a result of the amendments to its Constitution. In 2002, the Financial Accounting Standards Board (FASB) and the IASB issued a Memorandum of Understanding (MoU) known as the Norwalk Agreement, acknowledging their joint commitment in developing high quality, compatible accounting standards that could be used for both domestic and cross-border financial reporting. The two Boards were committed in improving and converging their respective accounting standards. The differences between U.S. GAAP and IFRS have become fewer and narrower as a result of the convergence project. The first widespread use of IFRS was in 2005 with the incorporation of IFRS in the European Union. In 2007, the SEC issued the "Concept Release on Allowing U.S. Issuers to Prepare Financial Statements in Accordance with International Financial Reporting Standards" (2007 Concept Release) to request public comments on whether U.S. issuers should be allowed to prepare financial statements in accordance with IFRS. Beginning in 2008, the SEC started to allow foreign companies that listed securities in the U.S. to file financial statements prepared in accordance with IFRS without reconciliation to U.S. GAAP. In November 2008, the SEC issued the "Roadmap for the Potential Use of Financial Statements Prepared in Accordance with International Financial Reporting Standards by U.S. Issuers" (2008 Roadmap) to propose a roadmap, including a series of milestones to be achieved, of its consideration in the use of IFRS by U.S. issuers. Today, more than 120 countries require or permit the use of IFRS in varying degrees, either as originally issued by the IASB or as modified by a particular jurisdiction, for the preparation of financial statements by publicly held companies.

\section{WORK PLAN}

The Work Plan detailed six specific areas of consideration for the SEC staff to address before a potential move to a system incorporating IFRS for U.S. issuers. These areas are the quality of IFRS, the independence of the IASB, the investors' knowledge of IFRS, the impact on the U.S. regulatory environment, the impact on U.S. issuers, and the human capital readiness. These are the issues and concerns raised either in the 2008 Roadmap or by the respondents to the 2008 Roadmap.

\section{A. Quality of IFRS}

To fulfill the SEC's mission of protecting investors, the accounting standards that are incorporated into the U.S. financial reporting system must be of high quality. The SEC staff indicated that the evaluation of the quality of IFRS would be based on its comprehensiveness, its auditability and enforceability, and the comparability of financial statements prepared under IFRS.

Because of its relative youth and its initial objective of providing general worldwide accounting standards, IFRS is not as developed as U.S. GAAP in some areas. For example, IFRS lacks guidance for some topical areas such as accounting for certain common control transactions. IFRS also generally lacks guidance for industry-specific issues. The SEC staff indicated that in its evaluation of the comprehensiveness of IFRS it would analyze how companies, auditors and investors managed those situations in which IFRS provides no or limited guidance in order to identify areas in which additional IFRS guidance is needed.

IFRS guidance is often less detailed and prescriptive than is U.S. GAAP and requires more judgments to be made by preparers and auditors. Some respondents to the 2008 Roadmap had expressed concerns regarding the risk of opportunistic accounting and the potential unfair criticisms by regulators, investors and others of the accounting conclusions of preparers and auditors. In addition, there were suggestions that both the preparers and auditors will need to be comfortable with the necessity of making more judgments and maintaining proper documentation to justify their conclusions and that legal and regulatory environments may need to be adjusted so that well-reasoned professional judgments are respected. The SEC indicated that it would analyze factors that may influence, and identify potential changes to improve, the auditability and enforceability of IFRS. 
One of the major benefits of a single set of global accounting standards is the increased comparability of financial information from companies around the globe. Currently, more than 120 countries require or permit the use of IFRS in varying degrees. However, some countries and jurisdictions crave out selectively or modify some standards. Furthermore, IFRS, in certain areas, permits more alternative accounting treatments than does U.S. GAAP. Coupling these with the concerns of comprehensiveness and enforceability, comparability could be undermined. The SEC staff indicated that it would assess the degree of, analyze factors that may influence, and identify ways to improve, the comparability of financial statements prepared under IFRS on a global basis.

\section{B. Independence of the IASB}

Another important consideration in the evaluation of IFRS is whether the standards are set by an independent standard setter and for the benefit of investors. IFRS is set by the IASB, which is funded and overseen by the IFRS Foundation. The IFRS Foundation is governed by 22 trustees and the IASB is composed of 14 members (to be increased to 16 members by July 2012) appointed by the IFRS Foundation. According to the IFRS Foundation Constitution, the appointments of IASB members are such that the IASB is not dominated by any particular constituency, geographically or professionally. A Monitoring Board was established in 2009 to enhance the public accountability of the IFRS Foundation. The IFRS Foundation Monitoring Board is composed of public capital market authorities, including the SEC, charged with the adoption and recognition of accounting standards used in their respective jurisdictions. The IFRS Foundation Monitoring Board approves and monitors the Trustees of the IFRS Foundation and serves as a link, on an international basis, between accounting standard-setters and those public authorities that oversee accounting standard-setters. The SEC staff indicated that it would analyze the composition and operations of the IFRS Foundation, the IFRS Foundation Monitoring Board, and the IASB to assess the ability of the IASB in independently and objectively developing accounting standards for the benefit of investors.

\section{Investors' Knowledge of IFRS}

A major benefit to investors of a single set of global accounting standards is the improved comparability of financial information presented by companies around the globe. But, this benefit will be realized only if investors understand these standards. Despite the convergence efforts to date, IFRS still differs from U.S. GAAP in a number of areas. For example, IFRS permits revaluation of property, plant and equipment while U.S. GAAP requires historical cost. IFRS generally does not allow different accounting treatments for different industries while U.S. GAAP provides specific standards for a number of industries. As a result, the incorporation of IFRS into the U.S. financial reporting system may require significant investor education regarding IFRS. On the other hand, it was suggested that U.S. investors may already possess some understanding of IFRS because of the widespread use of IFRS by foreign companies. The SEC staff indicated that it would try to assess the current level of U.S. investors' knowledge of IFRS and identity actions that may need to be taken to ensure investors having a sufficient understanding of IFRS prior to the potential incorporation into the U.S. financial reporting system.

\section{Impact on the U.S. Regulatory Environment}

In addition to filing financial statements with the SEC, U.S. issuers often provide financial information to a wide variety of other federal and state regulating agencies for different purposes. These regulators, including industry regulators and tax regulators, frequently rely on U.S. GAAP as a basis for their regulatory report requirements. Some respondents to the 2008 Roadmap had questioned, with the incorporation of IFRS, whether these regulators will continue to accept financial statements prepared for SEC reporting purposes as a starting point for regulatory filings. Their concern was if regulators continue to accept SEC-based reporting, any changes in the reporting as a result of the incorporation of IFRS can have regulatory impacts. For example, IFRS does not permit the use of the last-in, first-out (LIFO) inventory method. As a result, a company that reports in accordance with IFRS will be required to use a different inventory method and cannot use LIFO for income tax reporting because of the LIFO conformity provisions of the Internal Revenue Code. The effect on its taxable income can be substantial. Furthermore, there are also questions as to how a move to IFRS may affect the SEC's relationship with the standard setters, the FASB (the current U.S. accounting standard setter) and the IASB (the setter of IFRS). The SEC staff indicated that it would analyze the impact of the incorporation of IFRS on rules and procedures of the SEC, the FASB's ongoing role in accounting standard setting, and other regulatory environments. 


\section{E. Impact on U.S. Issuers}

The costs, effort, and time involved with a move to IFRS can be considerable. Companies may have to significantly modify their accounting systems as a result of the move. Some respondents to the 2008 Roadmap had expressed the concern that the benefits of such a move may not outweigh those costs, particularly for smaller companies and companies with limited international operations. Another concern raised is that many companies' contracts are, either explicitly or implicitly, based on U.S. GAAP, contract renegotiation may be required due to a move to IFRS. Also, some are concerned about the lower recognition threshold and additional disclosure requirements for loss contingencies under IFRS. The SEC staff indicated that it would consider the impact of the incorporation of IFRS on U.S. issuers in the above areas.

\section{F. Human Capital Readiness}

The readiness of all parties involved in the financial reporting system is an important consideration in the incorporation decision. These parties include investors, issuers, auditors, regulators, and educators. The AICPA has developed the www.IFRS.com website with a goal of providing a comprehensive set of resources related to IFRS for accounting professionals and other parties involved in the financial reporting system. Most of the larger accounting firms in the U.S. have also made more materials about IFRS available to the public. On the other hand, some of the respondents to the 2008 Roadmap had expressed concerns about the challenges faced in training both existing and future accounting professionals in utilizing judgment in the application of less prescriptive standards and about the possibility that smaller and less globally-oriented audit firms may have fewer or dedicate fewer resources to the training of their personnel regarding IFRS and become less competitive as a result of the incorporation of IFRS in the U.S. financial reporting system. The SEC indicated that it would evaluate the sufficiency of the IFRS education and analyze the possible effects of IFRS incorporation on audit quality, cost, and audit firm concentration and competitiveness.

\section{PROGRESS REPORT}

In October 2010, the SEC staff published a progress report (2010 Progress Report) to the Work Plan to provide an update of its efforts, preliminary observations, and works to be done regarding the six areas of consideration stated in the Work Plan. In the area of the quality of IFRS, the SEC staff indicated that it was analyzing IFRS as issued by the IASB and IFRS as applied in practice. For example, the SEC staff was comparing U.S. GAAP with IFRS and analyzing how investors, preparers, and auditors managed situations in which IFRS provides less guidance than does U.S. GAAP to evaluate the comprehensiveness of IFRS; analyzing challenges in the audit of financial statements prepared under IFRS and the enforcement of IFRS, how auditors, litigators and regulators managed these challenges, and accounting-related enforcement actions to evaluate the auditability and enforceability of IFRS; reviewing financial statements prepared under IFRS to evaluate of their comparability in practice. In addition to providing an update on the efforts undertaken by the SEC staff in the evaluation of the quality of IFRS, the 2010 Progress Report also discussed how other jurisdictions incorporated IFRS into their financial reporting systems and indicated that most jurisdictions had incorporated IFRS through either the convergence approach or the endorsement approach. As described in the 2010 Progress Report, under the convergence approach, jurisdictions move their local standards toward existing IFRS over time, ${ }^{3}$ and under the endorsement approach, jurisdictions incorporate individual IFRS into their local body of standards with the option of making modifications to address specific issues or needs. Furthermore, the SEC staff indicated that it was also examining the role of national standard setters in jurisdictions using IFRS to identify potential future roles for the FASB if the SEC were to decide to incorporate IFRS.

Regarding to the independence of the IASB, the 2010 Progress Report mainly focused on the funding mechanism of the IFRS Foundation as the IFRS Foundation Monitoring Board was conducting a review of the governance structure of the IFRS Foundation and the IASB. It appeared that IFRS Foundation relied largely on the

\footnotetext{
${ }^{3}$ As stated in the 2010 Progress Report, the convergence approach is different from the convergence project undertaken jointly by FASB and IASB as the convergence project involves movement by both standard setters toward a new mutually agreed standard.
} 
fundraising effort of its trustees and did not have formal sources of funding. The 2010 Progress Report mentioned that about a third of the contributions to IFRS Foundation were from international accounting firms while less than $25 \%$ of jurisdictions that used IFRS as part of their financial reporting system contributed in 2009. The SEC staff indicated that it would consider the results of the IFRS Foundation Monitoring Board's governance review in its evaluation of the independence of the IASB.

In the area of impact on the U.S. regulatory environment, the SEC staff indicated that the main concern of regulators was the method of incorporation of IFRS due to the fact that U.S. laws, regulatory requirements and guidelines and contractual documents are often made reference to U.S. GAAP. Regulators had expressed to the SEC staff that using U.S. GAAP as the mechanism of incorporation would resolve a number of their more important issues. Another concern raised was the general lack of industry-specific guidance in IFRS. The SEC staff also indicated that it was assessing the effects of IFRS incorporation on federal and state tax regulations and reporting, audit regulation and standard setting, broker-dealer and investment company reporting, and U.S. private company reporting.

The 2010 Progress Report did not provide too many details regarding investors' knowledge of IFRS, impact on issuers, and human capital readiness except that the SEC staff had been reaching out to various constituents such as issuers, investors, academics, and members of accounting firms and professional associations to gather and analyze feedback and information in its consideration of those three areas.

\section{“CONDORSEMENT" APPROACH}

In May 2011, the SEC staff published a paper, "Exploring a Possible Method of Incorporation," (2011 Possible Method) as an update to the Work Plan. The staff paper outlined one possible approach for incorporating IFRS into the financial reporting system for U.S. issuers if the SEC were to decide to incorporate IFRS. As this approach blends aspects of both a convergence approach and an endorsement approach, it is termed "condorsement." Under the approach outlined in the 2011 Possible Method, U.S. GAAP would be retained, but the FASB would incorporate IFRS into U.S. GAAP over a period of five to seven years. During this transitional period, existing differences between IFRS and U.S. GAAP would be addressed with the objective that a U.S. issuer compliant with U.S. GAAP should be able to represent that it is compliant with IFRS by the end of the transitional period. The FASB would incorporate newly issued and amended IFRS into U.S. GAAP according to an established endorsement protocol such that the FASB would be able to modify or supplement IFRS when appropriate.

In the 2011 Possible Method, the SEC staff suggested a strategy for the transition that was based on a classification of the ongoing or expected standard-setting effect of the individual IFRS. The categories are (i) IFRS subject to MoU projects ${ }^{4}$, (ii) IFRS included on the IASB's current standard-setting agenda, and (iii) IFRS not subject to standard setting. As MoU projects are undertaken jointly by the FASB and IASB with the expectation that similar standards will eventually be issued, the SEC staff did not expect the incorporation of IFRS subject to MoU projects into U.S. GAAP would create major problem. For IFRS included on the IASB's current standard-setting agenda, the SEC staff suggested that the corresponding U.S. GAAP requirements should be retained intact until the issuance of new or modified IFRS by the IASB and that the FASB should participate in the IASB's standard-setting process. This FASB participation would be to ensure that these new or modified IFRS are of high quality and that U.S. perspectives are properly considered in the standard-setting process. Once these IFRS were finalized, the SEC staff suggested that the FASB would be to review them individually to determine how to properly incorporate them into U.S. GAAP. For IFRS not subject to standard setting, the SEC staff suggested that the FASB should first assess them earliest for incorporation as they are not expected to change in the near future and that prospective application of new requirements should be allowed whenever possible to reduce the volume of required system changes and the need for restatements.

\footnotetext{
${ }^{4}$ As used in the 2011 Possible Method, MoU projects refer to the joint convergence projects of the FASB and the IASB on financial instruments, revenue recognition, leasing, the presentation of other comprehensive income, fair value measurement, balance sheet netting, and the consolidation of investment companies.
} 
The SEC staff pointed out several advantages of the "condorsement" approach in the 2011 Possible Method. It believed that the approach could allow for a more flexible transition strategy in which the FASB would evaluate each of the IFRS individually to determine the timing and manner of transition and that a gradual incorporation of IFRS would require U.S. issuers and investors to adjust to fewer new standards in any given period. In addition, the SEC staff argued that the incorporation of IFRS by FASB endorsement would allow the option of modifying or supplementing IFRS when necessary and that retaining U.S. GAAP as the statutory basis of financial reporting for U.S. issuers would reduce the costs and complexity of IFRS incorporation for both regulators and issuers as U.S. laws, regulatory requirements and guidelines and contractual documents are often made reference to U.S. GAAP.

Based on the comments ${ }^{5}$ received by the SEC, the feedback to the "condorsement" approach has been mixed. While a majority of respondents are supportive to the general idea of incorporating IFRS into U.S. GAAP by FASB endorsement, many have questions regarding how the approach may work. For example, some question how the SEC and FASB will determine when modifications to IFRS are necessary. Given the fact that the FASB and IASB decided to follow different paths in some of their joint projects such as balance sheet offsetting and financial instruments, some argue that modifications will not be rare and a U.S. version of IFRS will result. If that is the case, the goal of a common set of high-quality global accounting standards will not be achieved, they question whether it is worth the effort to adopt IFRS in the first place. At the same time, some are concerned that if modifications are rare, U.S.-specific issues cannot adequately be addressed. Another issue raised is related to the future role of the SEC and FASB in the standard-setting process of the IASB and the mechanism that will be in place to protect the interest of U.S. stakeholders and to ensure the independence (both financially and politically) and accountability of the IASB. Others are concerned that IFRS may not be consistently applied, interpreted, audited, and enforced across jurisdictions.

On the other hand, some respondents have fundamental issues with the possible incorporation of IFRS into the U.S. financial reporting system. They are not convinced that a move to IFRS is an improvement over the current situation. Some of them argue that it has not been shown that IFRS is better than U.S. GAAP. Others question how comparability will be improved more than marginally with the many modifications to IFRS already adopted by various jurisdictions around the globe, the possible modifications in the U.S. endorsement process, and the lack of consistency in the application and interpretation of IFRS. There are also concerns that IFRS will allow more opportunities for dishonest managers to hide their criminal acts.

\section{COMPARISON OF U.S. GAAP AND IFRS}

The SEC staff published two more papers related to the Work Plan in November 2011. The first paper, "A Comparison of U.S. GAAP and IFRS," compared U.S. GAAP to IFRS. It also discussed the status of the convergence efforts undertaken jointly by the FASB and IASB in aligning various standards. The SEC staff noted that U.S. GAAP generally contains more detailed, specific requirements than does IFRS as IFRS usually provides a broad principle to be applied across industries with limited stated exceptions or specific guidance. It also noted that the differences in the conceptual frameworks of the FASB and IASB might have contributed to the differences of current U.S. GAAP and IFRS and future standard-setting. This SEC staff paper confirmed the general observations that there are still many differences between U.S. GAAP and IFRS despite the convergence efforts. However, the more important question is how these differences can be addressed to achieve the objective stated in the 2011 Possible Method that a U.S. issuer compliant with U.S. GAAP should be able to represent that it is compliant with IFRS by the end of the transitional period. Furthermore, because the FASB and the IASB had delayed indefinitely their efforts in developing a common conceptual framework, it is likely that they will sometimes follow different paths in future standard-setting.

\footnotetext{
${ }^{5}$ Comment letters in response to the 2011 Possible Method are available on the SEC Web site (http://www.sec.gov/comments/4$\underline{600 / 4-600 . s h t m l}$.
} 


\section{IFRS IN PRACTICE}

The second paper published by the SEC staff in November 2011, "An Analysis of IFRS in Practice," examined how foreign companies in the Fortune Global 500 had used IFRS ${ }^{6}$ in their financial reporting. It reported that while these financial statements generally appeared to comply with IFRS requirements, the comparability of these financial statements were adversely affected by the diversity in the application of IFRS and that this diversity was attributed to either the options permitted by IFRS, the absence of IFRS guidance, or in some cases even the apparent noncompliance with IFRS. In addition, the SEC staff indicated that the inadequate transparency and clarity of some companies' disclosures also contributed to the challenges of understanding and comparing their financial statements. The staff paper also provided a brief summary of frequent comments from the SEC's Division of Corporate Finance received by foreign companies that used IFRS in their SEC filings. While most comments were requests for clarification or additional information regarding the companies' accounting treatments or disclosures, in some cases, companies were questioned for apparent noncompliance with IFRS. It is important to note that, as stated by the SEC staff, the staff paper did not attempt to compare the use of IFRS in practice to the use of U.S. GAAP in practice. Therefore, it is not possible to draw any conclusion from the staff paper regarding the degree of consistency in the application and enforcement of IFRS in comparison to that of U.S. GAAP.

\section{FUTURE DIRECTIONS}

As of the first quarter of 2012, several of the MoU projects including those on financial instruments, leasing, and revenue recognition still have not been completed. It is unclear if they can be completed by the end of 2012. Furthermore, the IFRS Foundation Monitoring Board and the IFRS Foundation just concluded and published reports of their respective governance review and strategy review in February 2012. These delays have undoubtedly made the evaluation of the quality of IFRS and the independence of the IASB, the two areas of consideration that the SEC indicated to be the most relevant to its decision regarding whether to incorporate IFRS, more difficult and unfinished. In addition, the IFRS Foundation Monitoring Board indicated in its governance review report that starting in 2013, only jurisdictions that require the domestic use of IFRS can be its members. However, the IFRS Foundation Monitoring Board has not yet defined the term "use of IFRS." It is unclear if this new requirement may influence the SEC's decision as to whether, when, and how to incorporate IFRS.

What will the SEC do? One possible outcome is that the SEC decides not to incorporate IFRS into the financial reporting system for U.S. issuers. This outcome is the current situation and there will be two main competing sets of standards in the globe. The ideal result under this scenario will be that the differences between U.S. GAAP and IFRS will gradually be reduced through the efforts of the FASB and the IASB to the point that U.S. GAAP will eventually be a U.S. version of IFRS. One problem with this outcome is that U.S. companies, especially large multinational companies, will likely demand to be allowed to prepare their financial statements in accordance with IFRS in their SEC filings, an option currently given to foreign companies. This issue will need to be resolved as it is not too logical or reasonable to allow, for an extended period of time, different sets of accounting standards for domestic versus foreign companies in their SEC filings.

A second possible outcome is that the SEC decides to incorporate IFRS into U.S. GAAP using an approach similar to the "condorsement" approach outlined in the 2011 Possible Method. This outcome will likely result in U.S. GAAP being a U.S. version of IFRS because of the differences in the capital markets, political and economic environments, business practices, and regulations between the U.S. and many of the foreign countries. Under this scenario, it is likely that all companies (both U.S. and foreign) will have to follow U.S. GAAP in their SEC filings after the transitional period to improve the comparability of companies' financial statements.

A third possible outcome is that the SEC decides to allow U.S. companies to prepare financial statement in accordance with IFRS in their SEC filings. This outcome will result in two competing sets of standards in the U.S. and make comparison among U.S. companies more difficult.

\footnotetext{
${ }^{6}$ In this section, the term "IFRS" refers to the version of IFRS (as issued by the IASB or as modified by a particular jurisdiction) described in the companies' financial statements.
} 
A fourth possible outcome is that the SEC decides to require U.S. companies to prepare financial statements in accordance with IFRS in their SEC filings. Under this scenario, it is basically certain that foreign companies would also be required to do the same in their SEC filings.

For some of these possible outcomes, there are also variations with respect to optional or required early or delayed adoption or exemption. Based on the findings from the reports and papers published by the SEC staff to date, the most likely outcome will be the second aforementioned possibility; that is a U.S. version of IFRS through an incorporation of IFRS into U.S. GAAP. The SEC has gone too far to return to require reconciliation to U.S. GAAP for foreign filers reporting in accordance with IFRS. On the other hand, a switch to IFRS by U.S. companies may be too drastic a change because of the many existing differences between U.S. GAAP and IFRS. A U.S. version of IFRS through an incorporation of IFRS into U.S. GAAP may be the outcome most receptive by a majority of the U.S. constituents. There are already different versions of IFRS in use in other jurisdictions around the globe and IFRS can be used as a point of reference in comparing financial statements. Retaining U.S. GAAP can ease many concerns raised by regulators and companies and provide control and flexibility over the accounting standards used by U.S. companies.

\section{CONCLUSIONS}

Since the issuance of the 2007 Concept Release by the SEC, parties involved in the financial reporting system including investors, preparers, auditors, regulators, and educators have been waiting patiently for the SEC's decision on the potential move to IFRS by U.S. issuers. Many larger companies, in particular, multinational corporations prefer to be able to apply IFRS in the preparation of their financial statements as soon as possible. On the other hand, smaller and domestically-oriented companies question how the marginal benefits gained can justify the substantial costs incurred in switching to IFRS. The SEC has to strike a delicate balance between the interests of various parties involved. The SEC has indicated in its 2010 Statement that it will not incorporate IFRS into the financial reporting system for U.S. issuers unless such a change is in the best interest of U.S. investors and capital markets. Whatever decision eventually made by the SEC, hopefully, is indeed the most beneficial one for U.S. investors and capital markets.

\section{AUTHOR INFORMATION}

Wing W. Poon is an associate professor of accounting at Montclair State University. He received his Ph.D. in accounting from Louisiana State University in 1996. His research interests are in the area of financial reporting issues, international accounting standards, and taxation. His publications have appeared in Clarion Business and Economic Review, Midwestern Business and Economic Review National Accounting Journal, National Public Accountant, and Journal of State Taxation, among others. E-mail: poonw@ mail.montclair.edu

\section{REFERENCES}

1. IFRS Foundation. 2010. Constitution. Available at http://www.ifrs.org/NR/rdonlyres/0B820728-7F104877-8068-7B65D2A3058B/0/ConstitutionDec2010.pdf.

2. . 2012. Report of the Trustees' Strategy Review 2011. Available at http://www.ifrs.org/NR/rdonlyres/37493F6D-3E73-4ED8-A99323D57BC76B68/0/TrusteesStrategyReviewFeb2012.pdf

3. IFRS Foundation Monitoring Board. 2012. Final Report on the Review of the IFRS Foundation's Governance. Available at http://www.ifrs.org/NR/rdonlyres/2CABFD51-7F0E-47A5-BA99F7A8B4E99C6F/0/GovernanceReviewFinalReportFeb2012.pdf

4. Kroeker, James L. 2011. Remarks before the 2011 AICPA National Conference on Current SEC and PCAOB Developments. Available at http://www.sec.gov/news/speech/2011/spch120511jlk.htm

5. Securities and Exchange Commission (SEC). 2007a. Concept Release on Allowing U.S. Issuers to Prepare Financial Statements in Accordance with International Financial Reporting Standards. Release No. 338831. Washington, D.C.: SEC. 
6. 2007b. Acceptance from Foreign Private Issuers of Financial Statements Prepared in Accordance with International Financial Reporting Standards without Reconciliation to U.S. GAAP. Release No. 33 -

8879. Washington, D.C.: SEC.

7. 2008. Roadmap for the Potential Use of Financial Statements Prepared in Accordance with International Financial Reporting Standards by U.S. Issuers, Release No. 33-8982. Washington, D.C.: SEC.

8. 2010. Commission Statement in Support of Convergence and Global Accounting Standards, Release No. 33-9109. Washington, D.C.: SEC.

9. Staff of the Securities and Exchange Commission (SEC Staff). 2010. Progress Report. Washington, D.C.: SEC Staff.

10. _ 2011a. Exploring a Possible Method of Incorporation. Washington, D.C.: SEC Staff.

11. 2011b. A Comparison of U.S. GAAP and IFRS. Washington, D.C.: SEC Staff.

12. _ 2011c. An Analysis of IFRS in Practice. Washington, D.C.: SEC Staff. 


\section{NOTES}

